\title{
Indeterminacy, Ideology and Legitimacy in International Investment Arbitration: Controlling International Private Networks of Legal Governance?
}

\author{
Juan J. Garcia Blesa ${ }^{1}$ (D) \\ Accepted: 5 January 2021 / Published online: 22 February 2021 \\ (c) The Author(s) 2021
}

\begin{abstract}
This article connects the insights of post-realist scholarship about radical indeterminacy and its consequences for the legitimacy of adjudication to the current legitimacy crisis of the international investment regime. In the past few years, numerous studies have exposed serious shortcomings in investment law and arbitration including procedural problems and the substantive asymmetry of the rights protected. These criticisms have prompted a broad consensus in favor of amending the international investment regime and multiple reform proposals have appeared that appeal to the rule of law ideal as an instrument for increasing the acceptability of the international investment system. This article argues that the reliance of such proposals on jurisprudential approaches that fail to adequately accommodate the post-realist indeterminacy critique and take seriously the role of ideology in adjudication renders reform efforts unable to solve the legitimacy problems of the investment regime. The conclusions suggest the need to abandon implausible claims to depoliticization and face the methodological challenges posed by the promise of ideologically balanced assessments advanced by some rule of law theorists. The article finally points at the urgency to reform traditional approaches to doctrinal work in order to increase awareness of critical challenges and open up doctrinal methods to alternative methodological avenues.
\end{abstract}

Keywords Indeterminacy · Investment law and arbitration · Legitimacy · Ideology · Rule of law

Juan J. Garcia Blesa

Juan.garciablesa@fernuni-hagen.de

1 Faculty of Law, University of Hagen, Hagen, Germany 


\section{Introduction}

“...the principles that animate our social and political institutions are not self-interpreting thoughts or pure conceptual essences, but rather are ambiguous affairs, by no means immune from appropriation as tools of tyranny."

Susan Marks, 2001.

The rule of law ideal has become the common denominator of a wide range of proposals for the reform of the current international investment regime $[5,50,116] .{ }^{1}$ The shared purpose of these references to the rule of law is to solve the legitimacy crisis spawned by a growing body of evidence pointing at serious incoherencies and power asymmetries in international investment law (IIL) and its investor-state dispute settlement system (ISDS), notably investor-state arbitration (ISA) [6, 43, 47, 85]. These reform efforts aim at linking the moral force of the rule of law ideal to IIL and ISA in order to convince key stakeholders of the fairness of the regime [4, $67,127,132$, 167]. However, reformers are finding it hard to agree on what problems the reform should address and what rule of law standards it should follow as a result of which proposals deal with a disparate number of issues-ranging from institutional design to procedural and substantive law matters-and seem unlikely to have a comprehensive impact on the complex network of international investment agreements and arbitration rules and procedures that makes out the regime [123, 139, 148].

This article argues that the legitimacy problems of IIL and ISA as well as the difficulties to solve them by appealing to rule of law standards are caused by the current jurisprudential failure to adequately adjust the ideal of the rule of $l a w^{2}$ to the indeterminacy critique articulated by post-realist scholarship during the second half of the twentieth century. ${ }^{3}$ Only by adding this critical-analytical perspective to the study of the problems of IIL and ISA can the legitimacy crisis and some of its most

\footnotetext{
1 The most influential professional bodies and networks in the area of international law have joined this initiative. Cf. e.g. 2018 Report of the International Law Association's (ILA) Committee on the Rule of Law and International Investment Law, available at https://www.ila-hq.org/index.php/committees; and the 2019 Report of the Eighteenth commission of the Institut de Droit International (IDI) on the Equality of Parties before International Investment Tribunals and the IDI Resolution of 31 August 2019, available at https://www.idi-iil.org/app/uploads/2019/09/18-RES-EN.pdf.

2 The rule of law notion is relevant to this study only insofar as it is used as a legitimizing device in IIL/ ISA debates. Despite its aporias and deficiencies, the moral force of the rule of law ideal continues to summon strong and widespread social support across the world and is, therefore, a term whose importance must be reckoned with, cf. [95]. Notwithstanding, critics have repeatedly warned that the notion of " "the rule of law" has become meaningless thanks to ideological abuse and general over-use' (Judith N. Shklar. 1987. 'Political theory and the rule of law', quoted in [159, 139]). The attempt to identify a core or across-the-board understanding of the rule of law notion is beyond the scope of this work. Among the many possible legal and political approaches to the concept, this article focuses on the work of mainstream authors (e.g. $[2,3,86,91]$ ) insofar as they make a direct and significant effort to address the critical indeterminacy challenge while aiming at the development of the rule of law ideal. On the diversity of rule of law definitions, cf. [11, 20, 28, 34, 45, 144, 147, 159].

${ }^{3}$ Literature on post-realist/post-modern legal scholarship is immeasurable. Being aware of its internal heterogeneity, this work draws to a large extent on some elements of the version advanced by Critical Legal Studies, cf. e.g. [7, 8, 13, 26, 62, 64, 70, 72, 76, 78, 79, 128]. Cf. also more recently [105, 161].
} 
relevant consequences be effectively explained in legal terms and possibly acted upon. Connecting these critical insights to the IIL/ISA debate, this work concludes: (1) that jurisprudential attempts to downplay the role of politics in the law do not live up to the challenges posed by IIL/ISA reform; (2) that reform approaches predicated on such premises are ultimately unable to solve the problems of legitimacy of ISA; and (3) that the shortcomings exposed call for giving serious consideration to the constructive elements of critical jurisprudential alternatives that require the rearrangement of traditional understandings of doctrinal legal method[s] and decisionmaking in ISA.

In the main, the indeterminacy critique propounds that legal materials per se are unable to determine the outcomes of legal interpretation and decision-making which ultimately depend on the collective ethical/political tendencies of historical ruleapplier communities prompting a critical rethinking of rule-applying institutions, processes and outcomes (cf. e.g. [7, 68ff, 13, 28f, 26, 100ff, 72, 45ff, 76, 394ff, 79, $157 \mathrm{ff}, 308 \mathrm{ff}, 128,957,152$, 5ff]). While mainstream jurisprudence appears to have successfully accommodated the indeterminacy thesis and deactivated critical questions about the legitimacy of rule-application and rule-appliers [145, 86ff], the controversy is far from settled and discussions resurface routinely across different areas of the law about the scope and consequences of the problem of legal indeterminacy $[15,23,58,110,117,118]$. As this work shows, although certain approaches both in general jurisprudence [3, 91] and IIL [22, 40, 98, 149, 115ff] take this critique partially into account, they are ultimately sterile due to their failure to identify and keep in check the main consequence of indeterminacy within the theory and practice of IIL/ISA, i.e. the centrality of ideology—understood as the legitimation of systematic and unjustified power asymmetries through "the way meaning is generated, conveyed, apprehended and appropriated in particular contexts" [93, 112]. ${ }^{4}$

Admittedly, there are limitations in the use of the term ideology as an analytical tool that have been pointed out by critical scholars (e.g. [64, 12f, 79, 286f]). Legal "[d] ecisions are predicated upon a complex mixture of social, political, institutional, experiential, and personal factors ..." [70, 14] that cannot be reduced to totalizing claims about the homogeneity and causality of any deep-structure-be this "capitalism" for the left or "efficiency theory" for right-wing (neo)liberals/conservatives [79, 287]. This article, therefore, does NOT envisage the term in this strong systematizing sense. Rather, ideology is understood here as a tool to analyze certain legal ideas and practices (judicial and jurisprudential) in connection to their consequences in the global socio-political context, i.e. as a set legitimizing strategies of a particular (contingent) status quo [79, 288f, 293f]. More specifically, this article points at the well-established connection of ISA's legal strategies with the neoliberal political-economic discourses and practices described as financialization and marketization of the global economy and the consequences thereof, especially in terms of actual substantive shifts in the structures of social, economic and political power across the globe (see Sects. 3.2, 4 below).

\footnotetext{
4 Borrowing from the work of Susan Marks and others, ideology is conceived here as the relationship between meaning and the legitimation of power asymmetries [93, 111, 117], cf. also [94].
} 
In this sense, it is useful to note that much of the quarrel about the reference to ideology in the study of ISA seems to derive from its application by empirical surveys in connection to the unwarranted assumption that there is a "correct" interpretation of legal materials lurking in IIL from which arbitrators would deviate due to "extra-legal" factors $[52,267,168,234]$. Far from these or any other assumptions about supposedly "objective" interpretations of the law or the existence of a "neutral" stand-point in legal decision-making, this work draws on the notion of ideology as a tool to understand and explain widely-acknowledged rhetorical lines and doctrinal patterns identified in the theoretical construction and the practice of IIL and ISA and link them to a broader jurisprudential problematic (see Sects. 2, 3.1 below).

Consequently, this article does not look at the ideology of individual arbitrators, but at the ideology of ISA as a community that produces a legal (rhetorical) practice geared towards the legitimation of the particular elements of neoliberalism already mentioned. When looking at rhetorical patterns identified in ISA-in contrast to the New Rhetoric approach whose reference to social reality is "at best partial and obscure"- the perspective adopted in this work suggests that the study of the law is "to treat the rhetoric of law as a primary datum to be evaluated [...] against the background of the institutional power and social relations of inequality, of superordination and subordination, that underpin that rhetoric and determine its semantic content[...]" $[53,123 \mathrm{f}] .^{5}$

Since the 1990s the main jurisprudential responses to the critical indeterminacy thesis have concentrated on an attempt to assimilate the critique by trying to demonstrate that legal indeterminacy is merely relative and solvable [86, 998, 91, 26]. In this endeavor, mainstream jurisprudence has lowered the degree of legal certainty that classic positivism required as a feature of the rule of law and replaced it with a nuanced acknowledgement of the argumentative nature of the law that, they suggest, can be harnessed in turn by the doctrinal development of disciplinary boundaries and legal reasoning constrained by coherent professional conventions-perceived as radically different from unconstrained ideological or political debate [2, 212ff, 3 , 185f, 39, 1f, 91, 26-31, 189ff, 113, 337ff, 353f, 145, 88f]. This revised version of the rule of law offers predictability based on a professional consensus the legitimacy of which is principally measured and controlled by its coherence and persuasiveness within the interpretive community of rule-appliers-who are in turn characterized by their professional and ethical integrity [145, 88, 90, 91, 27, 203, 3, 182ff]. The effort to assimilate legal indeterminacy into mainstream legal discourse has led to a widespread interest in hermeneutics, liberal pragmatic jurisprudence, legal rhetoric and the question of how "the art of interpretation" can be best "operationalized" in practice by different groups of rule-appliers so as to achieve a variety of policy goals ([158, 587]; cf. also [73, 90]).

However, the serious shortcomings of these assimilation attempts become apparent in relation to the legitimacy crisis of IIL/ISA bringing the predicament of legal indeterminacy and its critical implications back into focus. The practical and

\footnotetext{
5 For more on the use of the term in this article, see Sect. 4 below. On the centrality of ideology critique in the work of CLS, cf. e.g. [8, 422ff, 26, 105ff, 63, 15ff, 19ff, 79, 147ff, 96, 279ff].
} 
theoretical neglect of the role of ideology and group bias in rule application as the ultimate effect of indeterminacy renders ineffectual mainstream recipes to control professional communities of rule-appliers and the extra-legal sources that inform their professional conventions. Even when the critical gist of legal indeterminacy is somehow addressed-e.g. through the abstract promise of ideologically balanced assessments in the application of the law [91, 171ff]-, the main jurisprudential strategies for the control or scrutiny of rule-appliers fall short of actually dealing with it. In the face of such shortcomings, mainstream jurisprudence falls back on an unwarranted trust in the ethical qualities and the ability of individual rule-appliers to fully understand the legal and extra-legal ideological influences dominant in their profession and remain critically independent from them. ${ }^{6}$ In the final analysis, reform attempts based on such premises remain blind to how indeterminacy is being mobilized by local and global neoliberalization forces to justify and retain a specific set of policies deployed during the last 50 years $[16,10 \mathrm{f}]$ often against popular will $[60$, $161 \mathrm{ff}]$.

In order to unpack these issues, Sects. 2 and 3 elaborate the argument that the origin of the legitimacy problems of IIL/ISA and the inability of reform attempts to solve them are connected to the jurisprudential failure to accommodate the critical indeterminacy thesis in a way that adequately accounts for the role of ideology in rule-application. Section 2 briefly examines the main jurisprudential attempts to curb the indeterminacy critique and Sect. 3 illustrates the failure of such attempts in relation to IIL/ISA. Finally, Sect. 4 suggests that the strong ideological traits that can be found in IIL/ISA continue to be presented as "non-political" mainly due to the lack of awareness of the relevant professional communities and their "background assumptions" under mainstream jurisprudence which also leads to a lack of meaningful control of ideology in doctrinal work. This section also suggests possible directions to overcome the methodological difficulties derived from the indeterminacy challenge.

\section{The Critical Indeterminacy Challenge and the Main Jurisprudential Responses}

It is not the aim of this work to review the massive body of literature dealing with the issue of legal indeterminacy from a critical perspective. ${ }^{7}$ As Kennedy suggests, "[e]verybody knows that legal reasoning is indeterminate." [79, 275] For the purposes of this article it will suffice to point at the central forms of legal indeterminacy that legal philosophers and linguists have identified and classified in different ways $[72,12 \mathrm{f}, 53$, ch. 6-7, 88, 4ff]. With the intention of facing the mainstream responses

\footnotetext{
${ }^{6}$ For a paradigmatic example of overreliance on professional ethics in international law coupled with the recognition of the lack of appropriate means of control-with somewhat chauvinistic undertones, see [61, 287ff].

7 Mainly originated and studied in common law systems, the legal indeterminacy critique also affects legal systems inspired by the European Continental tradition, cf. e.g. [24, 89].
} 
to the indeterminacy thesis in their own terms, this article follows the taxonomy advanced by Kutz that distinguishes between semantic, systemic and normative indeterminacy within the law [86]. All these forms of indeterminacy, proponents of the critical perspective claim, expose the central role of the political and moral tendencies and biases of professional interpretive communities in the application of the law [18] which result in a challenge to the rule of law ideal as a politically neutral system for justifying the exercise of public authority [9, 761ff, 777ff, 135, 42f].

Although mainstream jurisprudence has not replied in a uniform manner to the challenge, ${ }^{8}$ this section studies the main attempts to deactivate the critical kernel of the indeterminacy thesis. These attempts try to demonstrate that, while politics and ethics play a role in the consensus of professional communities, rule-appliers are always controlled by internal and external mechanisms of scrutiny upon which their legitimacy would rest. After defining more in detail what types of indeterminacy the article explores in relation to IIL and ISA, i.e. semantic and systemic indeterminacy, ${ }^{9}$ this part examines the main arguments against the critical indeterminacy thesis and points at some of their shortcomings that will be tested and further elaborated upon in Sects. 3 and 4.

\subsection{The Challenge of Semantic and Systemic Indeterminacy}

As far as the elements of IIL studied in this work are concerned, semantic indeterminacy can stem both from the vagueness or "open texture" and the ensuing "contextuality" of legal language as well as from the very source of words' meaning in general [86, 1004-1014]. First, the vagueness of legal language as a source of indeterminacy is a pervasive feature of law that acts above all in the application of the law and goes beyond the problem of factual determination. In other words, vagueness implies that the applicability of a legal term (e.g. "fair", "equitable", "treatment", "reasonable", etc.) to a particular situation is indeterminate and, contrary to what some scholars have suggested [54, 35, 281f], more factual investigations cannot help determine its content which requires a decision to expand or reduce its scope of application [86, 1004f]. Second, as pointed out by thinkers like Wittgenstein and Derrida, language cannot be understood as a list of rules or codex that tell us what meaning we can extract from words for this view cannot explain the room for play and innovation undeniably present in language ([164, para.151, 185, 201]; cf. also [30, 142]). ${ }^{10}$

\footnotetext{
8 Jurisprudential reactions range from assimilation to neglect to denial [79, 192ff, 105, 709ff]. While part of legal theory today and most of legal practice downplays or overlooks the issue of indeterminacy and its effects $[88,5,145,90,95,257]$, some legal scholars still fully reject legal indeterminacy and the notion that values, extra-legal theories and policy discussions inform the interpretation and application of the law $[158,586,15,80 \mathrm{f}]$.

9 Although normative indeterminacy as formulated by Kutz [86, 1020ff] is arguably the most powerful part of the critical indeterminacy thesis $[72,13,80]$, its relation to IIL/ISA is studied elsewhere.

10 About the use of the linguistic concept of code in law and its semiotic problematic, cf. [53, 65ff].
} 
Rather, our ability to generate meaning from words in new contexts seems to derive from the stable sharing of interests, understandings, judgments and a "form of life" among language users [164, para. 241f]. ${ }^{11}$ In view of these features, semantic indeterminacy represents a serious problem for legal justification because it renders the logical cogency of syllogisms ineffectual as a direct link between the legitimacy of the legislator and judges' decisions owing to the fact that the minor premise becomes in a pervasive manner a matter of judicial discretion detached from any nontrivial democratic legitimacy ([86, 1006]; see also [112, 833ff]). Similarly, the notion that meaning stems from sharing certain views and understandings within a community of users raises a crucial question regarding the role of dominant views and tendencies in a particular community — which may provide for predictability but are hardly a source of legitimacy [135, 19ff].

Adding to the semantic challenge, systemic indeterminacy emanates from the dependence of interpretation on "background assumptions" and the use of nondeductive reasoning in legal argumentation [86, 1014-1020]. First, background dependence derives from our need to rely on conventions or "environmental clues" to guess the meaning given to words by other speakers [86, 1015]. Yet, the context or facts upon which meaning is based are already mediated by our often unstated practical and theoretical assumptions or "frames" that give the impression that our legal conclusions are inevitably deduced from the law preventing the political and value assumptions involved in such "framing" operations from surfacing and being debated [69]. Second, argumentative indeterminacy arises from the use of techniques of practical reasoning or rhetorical argumentation ${ }^{12}$ that, even if crucial to achieving persuasion in the practice of lawyering, do not determine decision-making the way logical deductions appear to do [86, 1017f]. It is easy to see how the possibility of selecting among factual frames and non-deductive arguments renders law's materials seemingly incapable of determining legal decision-making by any distinctly nonpolitical methodology [70, 4f, 14f].

These types of indeterminacy expose rule-application as law-making and pose a legitimacy challenge to rule-applier communities and their professional conventions as the ultimate law-maker [79, 228ff] that should be subject to effective scrutiny and control by rule of law standards. ${ }^{13}$ Although the dominant jurisprudential responses to this critique have been successful within the context of national legal systems in partly averting the challenge, their weaknesses become painfully apparent in an area-international law_for which they were not primarily devised.

\footnotetext{
11 In fact, critical legal scholarship goes further in the critique suggesting that Wittgenstein's "situated form of life" is just another attempt to ground discourse on stable foundations ("more turtles") and, thus, a language game that makes no sense beyond its context [128, 938]. However, Wittgenstein's argument is accepted by critical pragmatics on the grounds that there is always already a "turtle" we are sitting on, i.e. interpretive communities (cf. [128] quoting Stanley Fish, "Fish vs Fiss", Stan LR 36:1325, at 1345), provided we remain aware and critical about such foundations and their practical implications [128, 939ff].

12 E.g. analogy, policy concerns, evaluative judgments, probability, varying levels of conceptual abstraction, etc., cf. [129, 91, 124ff].

${ }^{13}$ In this sense, one of the main themes of the rule of law ideal is precisely the limitation of the power to make laws, cf. [145, 115ff].
} 


\subsection{Main Jurisprudential Responses to Critical Indeterminacy: Control of Professional Conventions in Denial of Ideology?}

Whereas part of Western jurisprudence has fully rejected the critical indeterminacy thesis [166], meaningful engagement with this notion is not uncommon in current scholarship [158]. Among the latter position, responses have mostly come from liberal pragmatics [3, 112], interpretivism (e.g. [37]; cf. also [143]) or hermeneutics $[73,95]$, though other contributions pick elements from diverse strands and are difficult to classify (e.g. [91]). From these different reactions one can extract a short catalogue of the main arguments in support of the notion that indeterminacy is merely relative and, in any case, solvable. Owing to their relevance for the IIL/ISA debate, this section briefly considers the rationality of legal argument, coherence, the possibility of revision or "defeasibility" of professional consensus and the ultimate reliance on the ethical qualities of professional communities of rule-appliers.

One of the main contentions that detractors of the critical indeterminacy thesis advance is that neither semantic nor systemic indeterminacy have the effect of cancelling the possibility of rational argument and reflection-as distinct from purely conventional discourse or sheer group conformity-so that doctrinal tools of legal reasoning continue to be perfectly well-suited to produce rational justification and persuasive or "defensible decisions" [86, 1007, 1011ff, 1016, 91, 203]. However, both persuasiveness and "being reasonable" are in essence predicated on the previous "critical ranking of relevant values" operated by rule-appliers within a professional community with very nebulous limits in practice [91, 173]. Hence, in order to make up for this weakness, the reference to "substantive rationality" is buttressed with a general appeal to coherence [86, 1010, 1017, 1019, 91, 189ff, 37, 112f, 124, 158] - a crucial source of persuasiveness and legitimacy in modern societies [48, 30ff, 38ff, 39, 11ff].

Yet, reliance on coherence to curb the effects of indeterminacy presents at least two problems. First, coherence is hard to reconcile with parallel jurisprudential efforts to mitigate indeterminacy and increase predictability by developing highly structured systems of legal doctrine $[3,181 \mathrm{ff}, 39,12]$. The construction of disciplinary boundaries is meant to reduce the amount of rules potentially applicable to a particular case diminishing the potentiality of conflict between different rules and principles and, thus, constraining the choices available to rule-appliers $[39,6 \mathrm{f}] .{ }^{14}$ But this effort simultaneously reduces coherence between different, ever more dislocated normative areas [39, 10f]. In other words, more determinacy can only be achieved at the cost of reducing coherence and vice versa [39, 20]. And second, coherence is not equated with non-contradiction, but conceived as "making sense" by a value or set of values that can be traced back to some image of "a satisfactory form of life" [91, 193], thus, slipping back to the issue of dominant political and moral value preferences in a rule-applier community.

14 The delineation of such disciplinary boundaries is of course less than a "purely objective" business, $[39,13]$. 
Consequently, resort to rationality and coherence is ultimately dependent on the relevant professional communities' "shared, natural patterns of affect and reaction" $[86,1011]$ and the extra-legal sources they are willing to rely upon, including e.g. different economic theories [91, 188]. Against the obvious risks generated by reliance on relatively small and unelected professional groups, mainstream jurisprudence points at different means of control internal and external to the community. The main internal control mechanism would be the possibility of reexamination of legal decision-making and the defeasibility of professional consensus through the evaluation of the rationality of conflicting arguments and choices [86, 1017, 1019f, 91, 237ff]. Yet, if the existence of dominant understandings and visions of life is the main source of meaning and a defining feature of professional communities, this appeal to self-referential scrutiny seems somewhat circular, at least with regard to the most basic collective assumptions and beliefs that grant access to or membership in the community. One does not need to doubt the moral integrity of individual rule-appliers to see how the resort to professional ethics as a solution to this selfreferentiality [145, 88-90, 91, 27, 3, 182ff] bends the question about the necessary modes and scope of effective scrutiny of a professional community's background understandings, especially as such community understandings tend to "naturalize" particular power relations and produce the cognitive exclusion of non-mainstream alternatives [79, 292f].

Regarding external forms of controlling rule-applier communities, there is the notion that the presence of extra-legal grounds in rule-application can be justified provided that they have some connection, even if tenuous or weak, to previous legal materials-which include not only statutes, but all sorts of legal history, especially judicial precedents, principles, policies, etc. Such connection would establish a sufficient link between rule-appliers and the legislator's legitimacy for in such case the former would be choosing between values already legitimately "woven into the fabric of the law" ([91, 188, 203]; cf. also [37, 153f]). Yet, this misses the point of the indeterminacy challenge which does not so much posit that rule-appliers will choose just any value, whether it is vaguely derived from legal materials or not. On the contrary, the gist of the critical indeterminacy thesis is that precisely such legal materials already give plenty of room for powerful group biases and strategic reasoning by rule-appliers providing ample basis for judicial law-making with the concomitant risk of strategic use for dominant class interests [7, 73, 63, 16f, 31, 79, 155f, 162, $180 \mathrm{ff}, 228 \mathrm{f}]$.

However, this possibility is denied by opponents of the critical indeterminacy thesis for two reasons. First, judges simply do not make law; they just produce a collection of discrete decisions that, precisely because of the contingency generated by relative indeterminacy and the lack of generality of such decisions, only amount to a legitimate discretionality that is inevitably embedded in any legal system operated by humans [91, 170, 106, 671]. And second, mainstream jurisprudence puts strong emphasis on the possibility of public, rational scrutiny as a means to guarantee legitimacy and avoid abuse of such powers [49, 50f, 86, 1022].

This section has briefly presented the critical indeterminacy thesis in some of its forms and the main counter-arguments advanced to solve the challenge. These arguments propound the assimilation of indeterminacy into the unaltered operation of 
the law by relying on the rationality and coherence of legal work and celebrating the positive "function" that indeterminacy fulfils within pluralistic liberal legal systems $[91,26 \mathrm{f}, 88,1 \mathrm{f}]$. The collapse of all means of indeterminacy mitigation into the professional conventions of interpretive communities of rule-appliers is justified by the denial of judicial law-making and reliance on means of control like defeasibility and rational scrutiny over legal justification. The next section takes a closer look at how semantic and systemic indeterminacy actually unfold in IIL and how the jurisprudential explanations described here fail to account for the role played by ISA in IIL before advancing some conclusions.

\section{Indeterminacy and the Politics of IIL-The Law-Making in ISA}

There is an apparent paradox in talking about judicial law-making against the backdrop of legal indeterminacy. If legal texts are generally indeterminate, judicial texts cannot be more determinative of legal outcomes than statutory or treaty rules. In this sense, judicial decisions would only amount to a collection of discrete decisions that could never really produce a general legal policy. However, the notion of judicial law-making in this context does not imply that the texts of arbitral decisions are more determinate than the treaty law they are connected with. Rather, this notion points at the fact that the predictability associated with the rule of law does not depend on treaty texts or arbitration precedents - which are always open to reinterpretation in relation to every new case which accounts for the actual diversity in arbitration outcomes-, but on stable understandings and tendencies within the ruleapplier community that are expressed in the specific patterns of meaning and visions of human life and global governance embedded in ISA.

In order to establish these points, this section first identifies the indeterminacy present in IIL through the study of one of the central pieces of investment protection, the "fair and equitable treatment" clauses [32, 33]. It analyzes how informal and massive reliance on arbitral precedent becomes the main tool in the attempt to provide stability of meaning in IIL $[42,98]$ which is directly linked to the claim of arbitral law-making. While commentators try to rationalize and legitimize this in different ways, the very features of arbitral precedent-also riddled with semantic and systemic indeterminacy-point further at the ISA community and its "background assumptions" as the ultimate source of meaning in IIL [153].

\section{1 "Fair and Equitable Treatment" (FET) Clauses and the Use of Precedent in ISA}

Within the complex net of bilateral and multilateral investment agreements that make out the international investment protection regime today, FET has arguably become one of the main elements in terms of its practical application in ISA and its use by global investors to shunt state policy $[150,10,39,33,10] .{ }^{15}$ Formally, like

$\overline{15}$ The literature on FET clauses is vast. For a cursory, yet sizeable list of references cf. [68]. 
most other core norms of investment protection, ${ }^{16}$ FET clauses are crafted as legal standards that rely on broad and open-ended notions such as "fair", "equitable" and "treatment". ${ }^{17}$ According to the indeterminacy thesis, standards are essentially informal, general policy commands, as opposed to supposedly mechanically applicable rules [72, 15, 77, 1695ff, 1710f]. Although the legal form of a standard allows for more policy flexibility, it also stands in a relationship of tension with the rule-oflaw commitment to eliminate arbitrariness in the application of rules as a way to contain public power and safeguard some room for individual freedom [49, 39ff, 91, 25f, 147, 8f, 12]. This generates instability, oscillation and unsettled doctrinal conclusions due to logically or empirically unanswerable problems that always provide for a variety of plausible expansive or restrictive interpretations [72, 15f, 69, 252ff]. This exactly is what one can observe in the operation of FET in IIL and ISA practice [150, 10ff, 63, 92, 23ff].

Although the FET standard is articulated in somewhat different terms in the thousands of international investment agreements (IIAs) in force today, the diversity of such formulations can be reduced to two main types of clauses: on the one hand, FET combined with the international minimum standard of protection of foreign citizens (MST) or with a general reference to public international law standards (PIL); and, on the other, FET standing alone [36, 2, 149, 50ff]. Both types of clauses are riddled with uncertainty of meaning in relation to their content and scope as both formulations allow for different and inconsistent approaches [150, 59f]. In practice, no uniform interpretation can be guaranteed by textual formulations even for clauses of the same type and wording [150,8]. For instance, FET combined with MST or PIL has produced a confusing case-law as MST itself is an incomplete, vague and unclear standard derived from international customary law $[36,2,150,6,9,22,60$, $125,152] .{ }^{18}$ And FET standing alone-which can also be interpreted as equivalent to the MST $[125,153]^{19}$ - is even more flexible and expansive [150, 6, 59f].

Scholars and arbitrators have tried to construe a homogenous content for FET by selecting some elements from a growing body of arbitration precedent and rejecting alternative interpretations that exist within that body by presenting them as illconstrued or less frequently upheld by tribunals [33, 14f, 42, 334ff, 98, 283ff, 165,

\footnotetext{
16 Aside from FET, the main investor protection standards include "treatment no less favorable than domestic investors", "most favored nation treatment" and the "prohibition of expropriation without compensation" cf. [92, 4, 20].

17 Cf. e.g. Article 3(1) of the Moldova-Spain BIT (2006): "Investments made by investors of one Contracting Party in the territory of the other Contracting Party shall be accorded fair and equitable treatment and shall enjoy full protection and security. In no case shall a Contracting Party accord to such investments treatment less favourable than that required by international law"; and Article 3(1) of the Netherlands-Surinam BIT (2005): "Each Contracting Party shall ensure fair and equitable treatment of the investments of nationals of the other Contracting Party and shall not impair, by unreasonable or discriminatory measures, the operation, management, maintenance, use, enjoyment or disposal thereof by those nationals. Each Contracting Party shall accord to such investments full physical security and protection.".

18 On the MST generally cf. [29, 607ff, 31, 242ff].

19 Siemens A.G. v. Argentine Republic, ICSID Case No. ARB/02/8, award of 6 February 2007, para 289293.
} 
247ff]. However, such discarded items usually prove to be perfectly correct or "reasonable" approaches to each point of discussion that cannot be fully ruled out based on the available legal materials alone. More importantly, even when one looks into the elements that make out an interpretation of FET presented as "correct", they only refer forth to other equally vague notions that reproduce exactly the same problem of indeterminacy they try to solve in the first place. For instance, an element that is usually expected to endow FET with some stable substantive content is the notion of "legitimate expectations" which protects investments during their lifetime from the negative impact of changes in the domestic business and legal environment caused by state measures and policy modifications. ${ }^{20}$ Whether or to what degree foreign investments are protected by FET depends on what kind of investors' expectations and state policy changes are considered legitimate [150, 64]. But there are different, equally rational approaches to answering these questions.

On the one hand, some arbitral decisions adopt different variations of the socalled Tecmed ${ }^{21}$ doctrine which interprets the legitimate expectations of investors as a right to enhanced legal certainty and stability against virtually any adverse change in the legal environment and requires the highest level of domestic legal predictability, consistency and transparency from states to the point of freezing state regulatory powers with respect to foreign investors. ${ }^{22}$ On the other hand, in order to moderate the political effects of this doctrine scholars and tribunals try to develop further qualifications for the doctrine of legitimate expectations. Here again there is a variety of doctrinal alternatives.

For example, one such qualification connects the notion of "legitimate expectations" to "reasonableness" that is defined by reference to the domestic context taking "all circumstances" into account. ${ }^{23}$ Reasonableness is also defined sometimes by reference to "due diligence" which requires from investors a higher level of awareness about the political and regulatory local environment. ${ }^{24}$ Another way of qualifying "legitimate expectations" is by linking them to specific representations or actions

\footnotetext{
${ }^{20}$ Although strong arguments against"legitimate expectations" doctrine as an element of FET are also available cf. AWG Group v. Argentina, UNCITRAL, Judge Nikken's separate opinion to Decision on Liability, 30 July 2010.

${ }^{21}$ Tecmed v. Mexico, ICSID Case No ARB (AF)/00/2, Award, 29 May 2003, para.154.

${ }^{22}$ Cf. also Occidental v. Ecuador, LCIA Case No. UN 3467, Final Award, 1 July 2004, para.183, 190, 196; CMS v. Argentine Republic, ICSID Case No. ARB/01/8, Award, 12 May 2005, para.274; PSEG Global et al. v. Republic of Turkey, ICSID Case No. ARB/02/5, Award, 19 January 2007, para. 252f, 241; Enron v. Argentine Republic, ICSID Case No. ARB/01/3, Award, 22 May 2007, para.259f, 264-268 and Enron v. Argentina, Decision on the Application for Annulment, 30 July 2010, para.298-316.

Although this interpretation is rejected by many scholars and practitioners due to its "freezing" effects on state sovereign rights to regulate national economy, the freezing of state regulation continues to be a perfectly acceptable practice under certain types of the so-called stabilization clauses inserted in investor-host government contracts [131, 927ff, 934f, 940].

${ }^{23}$ Duke Energy v. Ecuador, ICSID Case No.ARB/04/19, Award, August 18, 2008, para.340; see also Continental Casualty v. Argentina, ICSID Case No.ARB/03/9, Award, 5 September 2008, para.261; see also Alex Genin, Eastern Credit Limited, Inc. and A.S. Baltoil v. the Republic Of Estonia, ICSID Case No. ARB/99/2, Award 25 June 2001, para. 347, 370.

${ }^{24}$ MTD Equity Sdn. Bhd. and MTD Chile S.A. v. Republic of Chile, ICSID Case No. ARB/01/7, Award of 25 May 2004, para.173-178.
} 
taken by states to attract investments. ${ }^{25}$ However, these representations can be limited by tribunals to specific contracts, licenses, permits, etc. ${ }^{26}$ or expanded to include any implicit state measure intended to entice foreign investment. ${ }^{27}$ The timeframe available to establish such representations is also flexible. While it is sometimes limited to the moment the investor decided to invest ${ }^{28}$; in some cases such representations are established at a later point in the life of the investment. ${ }^{29}$

Another doctrinal alternative is the "balancing" of investors' legitimate expectations against the legitimate regulatory goals of the host state. This balancing doctrine proposes different possibilities to assess the "reasonableness" of state measures "in light of the circumstances" in the host country. ${ }^{30}$ The vagueness of these notions, however, can hardly be corrected by additional references to principles such as "bona fide" 31 or proportionality ${ }^{32}$ as a measure of legitimate state action. Furthermore, the balancing test can be dismissed by tribunals if specific representations issued by the state are construed as constituting the terms or circumstances of the investment. $^{33}$

A further element that can well illustrate the scope of the FET standard's indeterminacy is the so-called "liability threshold" which defines the minimum level of seriousness of a breach committed by the state required to establish a violation of FET and trigger legal responsibility [150, 12ff]. In other words, although any type of state action or omission can potentially constitute a breach of FET, not every breach will generate liability. Here again, FET provides no clear benchmark and a variety of outcomes and interpretations is possible based on same or similar wording of the FET clauses [119, 24, 150, 13, 87f]. If FET is connected to MST, it may result in a higher threshold. ${ }^{34}$ However, the MST offers an unstable basis that refers forth to terms such as "egregious", "manifest" or "flagrant". These controlling notions open a wide space for factual interpretation especially as such standards are subject to

\footnotetext{
${ }^{25}$ Methanex Corporation v. United States of America, UNCITRAL, (NAFTA), Final Award, 3 August 2005, Part IV, Chapter D, p.5, para.7.

${ }^{26}$ Metalpar v. Argentina, ICSID Case No. ARB/03/5, Award on the Merits, 6 June 2008, para.186.

27 Glamis Gold, Ltd. v. United States, UNCITRAL [NAFTA], Award, 8 June 2009, para.627; Enron v. Argentina, ICSID Case No. ARB/01/3, Award, 22 May 2007, para.264-266; LG\&E v. Argentina, ICSID Case No. ARB/02/1, Award, 25 July 2007, para.130, 133.

28 Bayindir v. Pakistan, ICSID Case No ARB/03/29, Award, 27 August 2009, para.190; Duke Energy v. Ecuador, ICSID Case No. ARB/04/19, Award, 18 August 2008, para.340; AES v. Hungary, ICSID Case No. ARB/02/17, Award, 23 September 2010, para.9.3.8ff.

${ }^{29}$ Kardassopoulos v. Georgia, ICSID Case No. ARB/05/18, Award, 10 March 2010, para.434ff.

30 Saluka Investments B.V. v. The Czech Republic, UNCITRAL Rules, Partial Award, 17 March 2006, para.304-306.

31 Ibid., para.307.

32 Suez, Sociedad General de Aguas de Barcelona S.A. and Vivendi Universal S.A. v. Argentina Republic, ICSID Case No. ARB/03/19, Decision on Liability, 30 July 2010, para.264f; cf. also [22, 167ff].

33 Parkerings-Compagniet AS v. Lithuania, ICSID Case No. ARB/05/8, Award, 11 September 2007, para.332.

34 S.D. Myers Inc. v. Canada, UNCITRAL Rules (NAFTA), First Partial Award, 13 November 2000, 40 ILM 1408 (2001), para. 261, 263; Cargill v. Mexico, ICSID Case No. ARB(AF)/05/2, Award, 18 September 2009, para.285f, 292, 296; Glamis Gold Ltd v. United States, UNCITRAL Rules, Award, 8 June 2009, para.616f, 829 .
} 
evolution and may occasionally be taken to imply more stringent conditions of scrutiny on state actions today than they did a century ago. ${ }^{35}$ On the other hand, when FET is interpreted in isolation from MST the threshold is even less clear $[150,88]$.

Another attempt to fix the scope of FET is the inclusion of additional content in the text of IIAs. Some recent IIAs explicitly mention specific elements of FET such as denial of justice, breaches of due process and manifest arbitrariness among other notions. ${ }^{36}$ However, these enumerations may not always be considered as a closed list - a position that would allow for expansive interpretations [150, 29f]. And, even where the additional texture of FET in IIAs is taken as a closed list, the notions they contain are often just equally flexible and indeterminate themselves, especially as the weight given to domestic circumstances in delimiting each one of them is always uncertain [150, 33f].

In sum, as they try to stabilize and specify the vague content of FET, arbitral doctrines and treaty innovations fall into the infinite regress described by the critics $[128,943 \mathrm{f}]$. They refer back and forth to equally vague notions such as good faith, legitimate expectations, proportionality, domestic context, etc. which, when one tries to pinpoint their content, lead in turn to further open-ended notions and standards. ${ }^{37}$ In addition to the fact that these terms may raise quite different expectations depending on the cultural background or legal tradition of the actors involved in the process $[119,24]$, the latent possibility to expand or restrict the conceptual meaning and factual scope of application of these concepts produces a permanent oscillation between "subjective" arguments about the actions of the investor or the legal measures and attitudes adopted by the state on the one hand and, on the other, "objective" arguments about international standards and domestic circumstances (economic, social, political or legal). This oscillation allows for a wide range of solutions based on the same legal premises despite the intensive use of legal precedent.

\subsection{Precedential Indeterminacy and the Politics of ISA}

The conclusions of the analysis above unfold on two different levels. First, on a more descriptive note, it corroborates that the "open texture" of investment treaties $[22,160 \mathrm{ff}, 47,1585 \mathrm{f}, 92,19,98,290 \mathrm{ff}, 167,17,21]$ amounts to a serious and pervasive issue of semantic and systemic indeterminacy and illustrates the widespread use of arbitral precedent as a legal source of paramount importance in IIL and ISA [42, 333ff, 98, 285ff, 153, 281ff]. Second, and more significantly, it shows how even the

\footnotetext{
35 LFH Neer and Pauline Neer v Mexico (US v Mexico) (1926) 4 RIAA 60, pp. 61f.

${ }^{36}$ Cf. e.g. Article 2.5 of EU-Vietnam Investment Agreement (2019) at https://investmentpolicy.uncta d.org/international-investment-agreements/groupings/28/eu-european-union-; and Article 5(3) of the United States of America Model BIT (2012) at https://investmentpolicy.unctad.org/international-inves tment-agreements/model-agreements.

37 This is the case even in more properly technical questions different from economic discourse. For instance, in the context of environmental regulation, though reasonableness is normally construed on the basis of procedure, rather than scientific correctness, "[i]n dealing with process issues, the international tribunal will walk a fine line between adjudicating legal claims and deciding scientific disputes", [101, 49].
} 
use of arbitration precedent cannot per se solve the problem of indeterminacy pointing directly at the ISA community and its background assumptions as the ultimate source of predictable meaning in IIL.

There are in IIL scholarship different justifications of the central role of precedent in arbitral practice. On the one hand, in line with the jurisprudential mainstream examined above, there is a widespread "pragmatic formalism" that denies the value of arbitral precedent as a formal source of IIL and pays lip service to the formal subsidiary role of "judicial decisions" in PIL (Article 38.1.d. of the Statute of the ICJ), while heavily relying on precedent in practice as an informal primary source [153, 277-281]. On the other hand, a few scholars suggest that the use of standards in IIL implies a "delegation of legislative authority" by virtue of which arbitration tribunals become a legitimate law-making authority in defining the meaning and scope of investment protection standards [19, 66, 98, 281]. Whatever the position in this regard, the underlying general assumption is that the coherent and consistent use of arbitration case-law can provide some determinacy and constrain the power and freedom of interpretation of arbitrators bringing predictability and legitimacy to the investment regime [98, 285ff]. ${ }^{38}$ This implies the recognition of the indeterminacy of investment treaties coupled with the claim that precedent can deliver a measure of objectivity and technical necessity that would derive from the spirit of this "jurisprudence constante" [14]. ${ }^{39}$ And so, a large body of arbitration awards has become the main source of IIL in practice.

However, as recent debates at UNCITRAL Working Group III for investor-state dispute settlement reform (WGIII) show, one of the main problems that IIL reformers have identified is precisely the lack of consistency and coherence of investment arbitration outcomes that, despite the use of precedent, affects even the interpretation of same or similar investment treaty provisions. ${ }^{40}$ This confirms that the idea of a necessary meaning based on a previously assumed objective or inherent content deeply embedded in arbitration precedent is not tenable. Not only offers arbitration precedent a variety of distinct and equally reasonable doctrinal possibilities; the formal and factual scope of each doctrine can be reasonably broadened or narrowed to support different values and objectives in every case $[150,11,13] .^{41}$ As a result, the massive use of arbitration precedent fails to solve the indeterminacy of investment treaties owing not only to discrepancies between different arbitration doctrines, but

\footnotetext{
38 Report of UNCITRAL Working Group III [Investor-State Dispute Settlement Reform] on the work of its thirty-fourth session (Vienna, 27 November-1 December 2017)—Part II (A/CN.9/930/Add.1/Rev.1), para.11.

39 In this large pool of arbitral decisions arbitrators and scholars search through to define "common strands and directions in cases that would shed light on the meaning of the FET obligation" [150, 43].

40 A/CN.9/930/Add.1/Rev.1, para 9ff, 15f; cf. also [130].

41 The indeterminacy of investment legal materials renders it necessary for international arbitrators to resort, for instance, to purposive reasoning (cf. e.g. Suez, Sociedad General de Aguas de Barcelona S.A. and Vivendi Universal S.A. v. Argentina Republic (ICSID Case No ARB/03/19), Decision on Liability, 30 July 2010, para. 218; and [146, 58f, 63]) which restating the classic indeterminacy thesis, no matter how much self-restraint arbitrators may display, implies discussions about policy goals that are grounded in different ideas about substantive justice—an indeterminate notion itself [151, 197f, 10, 156].
} 
also due to disagreements on the meaning and scope of each of those doctrines. ${ }^{42}$ The proposal to reduce emphasis on coherence and consistency in the use of precedent in ISDS $^{43}$ is not only a recognition of the indeterminacy problem; it is also bound to exhacerbate the incoherence of IIL vis-à-vis other branches of international law as illustrated by the controversies regarding the position of human rights-especially economic and social rights of local populations - and the environment in relation to foreign investment protection $[1,6,83,109,140,165] .{ }^{44}$

However, for all the indeterminacy of IIL materials and the incoherence of ISA outcomes, investment arbitration precedent is not just a collection of contingent decisions disconnected from each other. There actually are some professional conventions that generate stable practices and patterns of meaning within ISA. ${ }^{45}$ For instance, one such pattern is the "failed law premise", identified by Ureña, whereby investment arbitration usually follows a narrative that "features domestic law as failed (or about to be), and therefore in need of correction or complement by the investment tribunal." $[153,300]^{46}$ This general pattern hinges on an entrenched disregard for domestic law [100, 246, 167, 19f] and is closely linked to a well-documented tendency of investment tribunals to find developing states in breach of their investment protection obligations significantly more often than developed states [12, $411,43,59,132,1157 \mathrm{ff}]$. Through the analysis of this tendency, Odumosu identifies three technologies or strategies frequently deployed by investment tribunals which encompass: the exclusion of any genuine participation of grassroots movements from host societies that is not mediated by NGO workers "socialized" in IIL ${ }^{47}$; the systematic treatment of public interests as a private property issue ${ }^{48}$ and, finally, the purported separation of investment law from its serious socio-economic, political and cultural ramifications under the slogan of "depoliticization" [99, 263ff]. ${ }^{49}$

\footnotetext{
42 As Beckett explains, there is no better proof of indeterminacy than the scholarly and institutional efforts to "correct" it by advancing alternative interpretations and generating a variety of equally plausible arguments that intensifies the very problem they try to solve $[10,150 \mathrm{f}]$.

43 A/CN.9/930/Add.1/Rev.1, para. 11, 17, 20ff. This attempt, however, is unlikely to succeed due to the potential application of the "Most Favored Nation" (MFN) standard [36].

44 Given the difficulty in setting a clear measure for the demand of coherence [37, 1997, 105ff, 2, 213, 91, 190], any conspicuous lack of it raises a number of questions that potentially undermine the legitimacy of the law-and of rule-appliers, cf. [118, 344ff].

45 Though not specifically dealt with below, such patterns are closely linked to the professional and institutional policy dynamics that drive the investment arbitration industry, cf. [38, 12ff, 141, 240ff]. For an analysis of bias in ISA as an institutional effect, see [17, 572ff, 43, 37].

46 For a somewhat nuanced example of this narrative in IIL scholarship, cf. [132, 1161f].

47 Despite limited participation as amicus curiae, "the Cochabamba protests were as close as one usually gets to hearing the subaltern's voice in the foreign investment law debate" $[99,260,265]$. On the general lack of standing of citizens affected by investment in arbitration proceedings, cf. [46]. For a more comprehensive treatment of the narrow participation of the population of developing countries in ISA, see [65, 206ff, 120, 121f].

48 Also connected to the disciplinary sensibility and techniques habitually deployed by those involved in arbitration regardless of their personal beliefs [133, 468].

49 This is operated through the misrepresentation of the exclusion of interstate politics as the exclusion of all politics, cf. e.g. [84, 111, 48ff, 4, 975]. Such strategies also typically include the use of certain notions of economic "efficiency" which tend to discard other values and goals [157].
} 
Nevertheless, these and other patterns in investment decision-making are indicative of a political orientation intended or unintendedly aligned with neoliberal postulates [114, 134, 576, 138, 163, 23]. Legal discourses that deal with economic matters of the highest social and political importance through the narrow lens of individual private property $[6,2804 \mathrm{f}, 107,676 \mathrm{ff}, 693,133,452 \mathrm{ff}]$ and construe corporate capital rights as universal, fundamental rights [97, 243] while weakening public protection of the environment ${ }^{50}$ and the rights of local populations in the name of global free movement of capital $[27,488,107,679 \mathrm{ff}, 692,155]^{51}$ give expression to a political economy that promotes the marketization of all human transactions on a global scale and the privatization of governance across borders through a "polycentric web" of international rules and non-state institutions that displaces and alters traditional state goals and structures [47, 1521f, 1544f, 1625, 60, 3f, 7, 72-78, 126, $418 \mathrm{ff}, 136,271 \mathrm{f}, 160,4 \mathrm{f}] .^{52}$

These features expose two central aspects of ISA. First, in view of the fact that such arbitration parterns do not stem from the indeterminate IIL materials themselves, their source is revealed within the "background assumptions" and stable sharing of interests and understandings that define this community of IIL language users, i.e. the interpretive community of ISA itself. While this may offer a modicum of predictability or stability of meaning, ${ }^{53}$ the heavy impact of ISA on domestic and global public interest and policy [126, 409ff] operates a massive power-shift from sovereign states to the ISA community transferring in practical terms a broad

\footnotetext{
${ }^{50}$ For instance, the neglect of environmental aspects may take place through the narrow construction of the possibility for states to raise counterclaims, cf. [67, 33f, 36f]. For more information about the shortcomings and possible reform of state counter-claims within the UNCITRAL system, cf. UNCITRAL Working-Group III reports on Multiple proceedings, reflective loss and counterclaims by respondent States, available at https://uncitral.un.org/en/multipleproceedings.

51 Since state intervention and social and environmental protection are closely intertwined, any state measure can potentially be construed as impinging on free market goals, cf. e.g. S.D. Myers Inc. v. Canada, UNCITRAL Rules (NAFTA), First Partial Award, 13 November 2000, 40 ILM 1408 (2001), para. 155 (holding that domestic environmental protection measures which indirectly strengthen local industry are an unlawful means to protect the economy). This effect also derives from the increased resort to secret settlement of arbitration claims, cf. [57, 28ff].

52 Though neoliberal discourse is not homogenous, the dynamic interaction between global economic postulates, local manifestations and reform rhetoric to achieve a "better neoliberalism" produces a certain "economic logic" that converges around the myth of global free economic transactions [160, 6]. Whereas the main policy result of it is the creation and maintenance of a particular system of wealth accumulation that favors the interests of a small part of society [60, 19, 31ff], the justification of the ideas and dehumanizing practices involved is deployed through the "depoliticizing, naturalizing and ritualizing functions" of a rhetoric of sacrifice that would lead to the quasi-scatological advent of the free-market based "good life" [160, 7f]. For a more in-depth study of how neoliberal ideology is reproduced in dispute resolution mechanisms outside the state masking power asymmetries and advancing the criterion of "utility maximization", cf. [25, 63ff, 67, 69].

53 This also explains why investment arbitrators seem to experience some sort of constraint in their work. As one FET expert would put it in relation to the use of precedent, "[d]espite many fears-namely, that the standard would offer an enormous discretionary power to the arbitrator-the arbitrator is in practice controlled in his discretion by this objective element. His margin of manoeuvre is much more limited in practice than in theory." [149, 133] That the source of constraint claimed by experts and arbitrators is mistaken - as demonstrated above- does not necessarily entail that such feelings of constraint are merely dellusional or intentional misrepresentations.
} 
law-making authority from the former to the latter $[98,300,122,179 \mathrm{f}, 188 \mathrm{ff}, 153$, 295ff]. This, and not the indeterminacy of IIL, is the actual source of illegitimacy [47, 1585] - along with the substantive outcomes of such patterns. And second, these patterns and the way they are produced are highly problematic in terms of the rule of law ideal for, no matter what the personal ethics or beliefs of arbitrators, they actually serve to advance a particular politics as "non-politics" which makes ISA virtually impervious to other views of the world, society and human life characterizing ISA as a technology for the implementation and legitimation of such politics.

The last section considers how the problems discussed above thwart the traditional means of control over rule-applier communities advanced by mainstream jurisprudence undermining the legitimacy of ISA by mainstream rule-of-law standards. Finally, it propounds that only the incorporation of some form of ideology critique into such scrutiny efforts can potentially help address these shortcomings.

\section{Legitimacy as Review and Rationality Control in IIL/ISA? The Rule of Law as Ideology Critique}

The notion that the predictability of meaning associated with the rule of law derives from the "consensus, concerns and boundaries" existent within the "international collegiality of elites from different countries" is, of course, not new in international legal theory $[154,480] .{ }^{54}$ Neither are international lawyers unfamiliar with the idea that such interpretive or professional communities produce strong "structural biases" $[55,121,247,10,152,82,598 \mathrm{ff}] .{ }^{55}$ And, as a matter of fact, the existence of a specific interpretive community of rule-appliers in ISA has been abundantly confirmed by empirical research showing the intellectual homogeneity $[38,115]$ and collective tendencies in decision-making of investment arbitrators [17, 43, 156, 137, 31].

Moreover, there have been calls among international scholars to take seriously the study and scrutiny of "background factors of interpretation" that act as the fundamental framework of legal reasoning and decision-making, yet little progress has been done along these lines [158, 585f, 588]. More specifically, in the area of IIL there have been few attempts at developing a meaningful system of evaluation and control of ideological factors in relation to ISA's decisions and underlying policies (e.g. [153]). In line with the failure to address the collective law-making power of the ISA community and its stark ideological traits as a structural source

\footnotetext{
54 Especially since the acknowledgement of the failure of the "original intent" jurisprudence [154, 504] and the rest of interpretive methods proposed in Articles 31-33 of the 1969 Vienna Convention on the Law of Treaties to provide a basis for determinative legal interpretation [90, 188f].

55 Although the term "epistemic communities" also tries to capture the same collective aspect of meaning creation in decision-making, it is seen by critics as an attempt at legitimizing the role of experts in the international governance of domestic affairs through the replacement of political debate with a reference to some objective non-political knowledge and technocratic (legal) discourses, [74]. Furthermore, being a notion that draws on the objectivizing discourse of the natural sciences, its applicability to international lawyering is far from uncontroversial even among its proponents who consider that lawyering lacks the required technical objectivity $[56,3]$.
} 
of illegitimacy, the most consequential ISA reform proposals do concentrate on the procedural defeasibility or revision of specific arbitration decisions understood as discrete and disconnected events. Such initiatives reach out to state elites and take little of the socio-political impact of the IIL/ISA project into account $[167,20 \mathrm{f}] .^{56}$ Despite the pleas to become more acceptable and persuasive for larger audiences [126, 425], reform proposals fail to revise the economic-political rationality upon which the professional persuasiveness standards of ISA are based, not only when they advocate for the "internal reform" of arbitration doctrines by the ISA community itself $[66,71,81,87,102,104,107,108]$, but also when the goal is the establishment of formal appeal mechanisms with permanent or ad hoc revision tribunals $[5,44] .^{57}$

This comes hardly as a surprise as the collective sharing of basic interests and understandings mentioned above is not simply a condition for membership to the ISA community; it is also a condition for participation therein and cannot be abandoned by individual investment arbitrators at will whatever their personal views. As deep-rooted, unstated practical and theoretical assumptions or "frames" create an entrenched sense that legal arguments are non-political, they prevent political assumptions and value rankings from surfacing and being openly debated for what they are, i.e. contingent images of a global form of life. As long as the rationality standards by which reexamination takes place are the uncritical product of unstated interests and views on politics, ethics and the society; as long as they show no clear awareness of the ideological nature and background of their activity and give no adequate room for genuinely open and broadly representative debate about its politics, the proposed mechanisms of defeasibility seem utterly circular. As the debates at UNCITRAL WGIII confirm, even if ISA reform might help overturn some decisions in particular cases, piecemeal revisions cannot substantially challenge the ideological framework on which the asymmetric power of ISA is predicated and deployed as an instrument of private global governance at the service of financial globalization. ${ }^{58}$ Similarly, widespread suggestions to expand the basis of applicable law in ISA to include human rights law are, under these circumstances, likely to prove sterile in terms of adding political diversity to ISA for a neoliberal discourse

\footnotetext{
56 The problems of equating the interests of postcolonial states with those of their populations have been long established, e.g. [103, 347f, 352]. This becomes critical when complex constellations of local interests are reduced to the simplistic representation of the state-such simplification is in itself an ideological move [25, 74]. Against the use of the dichotomy state vs investor in the analysis of ISA, cf. [168, 238].

57 Cf. e.g. UNCITRAL Working-Group III proposals and discussions on Tribunals, ad hoc and standing multilateral mechanism, available at https://uncitral.un.org/en/working_groups/3/investor-state. Accessed 21 Oct 2020.

58 In this sense, UNCITRAL Working-Group III clearly identifies the improvement of the confidence of investors and the enhancement of international capital flows as "higher policy goals" in IIL/ISA reform, cf. Report of Working Group III (Investor-State Dispute Settlement Reform) on the work of its thirtyfifth session (New York, 23-27 April 2018=, A/CN.9/935, para. 37.
} 
on human rights as the product of global free market competition and efficiency is readily available to the arbitration community [75, 146f, 158ff, $79,308 \mathrm{f}] .^{59}$

Admittedly, there are aspects of the critical approach that can partially explain the neglect of the ideological dimension of ISA and the reluctance of legal theorists and practitioners to touch upon this complex issue. These aspects include the difficulty of identifying a workable notion of ideology itself [64, 12f, 79, 286ff, 294] and the doubts about how legal practice should integrate the critique into the rule of law ideal without losing professional identity [95, 252]. However, there are contributions that point at interesting possibilities. In a 2001 piece, Susan Marks proposes to recover the critique of ideology for international legal scholarship and defines it as the "analysis of the involvement of systems of meaning with relations of power" [93, 117, 94]. For Marks, ideology critique should be understood neither as a neutral categorization of different political traditions, nor as a matter of merely exposing the mistaken epistemological status of certain beliefs. ${ }^{60}$ Rather, this model of critique targets the ways in which legal discourses are deployed, not just because they are erroneous, but because of their function and ethical/political effects, i.e. the legitimation of power asymmetries that are "instrumental to injustice" [93, 111f, 115].

In the critique propounded by Marks, ideology is not conceived of as a monolith to be studied with the arrogance of an external observer. On the contrary, ideology exists in her view as a feedback loop between epistemological mistakes and the practices in which we all participate, not so much owing to unawareness of the mistaken nature of the assumptions that ground our practices, but due to inattention to how our "acting as if" actually shapes social reality [93, 113]. ${ }^{61}$ Accordingly, the "problem-solving" type of legal work, likely the most widespread among legal professionals, that "seeks to isolate problems and propose remedial action, on the footing of a framework of ideas and practices which is not itself in question" is also an ideological strategy that intended or unintendedly "helps to obscure and legitimate relations of domination" [93, 118f].

Therefore, the challenge is to a large extent methodological. The main obstacle to be overcome is not so much ideology itself, which seems inescapable for both internal and external participants in legal debate [54, 180], but its denial and concealment behind necessitarian claims to depoliticization. The preliminary methodological step then should be to create awareness about and describe the role played by such collective understandings in IIL reform and ISA practice. This includes the definition of the rule of law itself, e.g. when it is defined by focusing exclusively on state power as a threat to narrow notions of liberty ignoring global private power as a threat to material visions of liberty [49, 184ff, 147, 4].

\footnotetext{
59 For instance, the appeal to "human rights due diligence" in investment as formulated in the UN Guiding Principles on Business and Human Rights simply refers forth to another process without external participation, verification, monitoring or review led by corporate managers, cf. [59]. For a take on the limitations and ultimate reliance of "human rights due diligence" on ethical/political factors for its implementation, cf. [41, 162].

60 As implied in the most superficial level of the traditional critique of ideology [51, 13ff].

61 E.g. "acting as if labour relations were based on free exchange among equals".
} 
In the light of this, also the proposal that the rule of law must yield ideologically balanced assessments [91, 171ff] can be regarded as a call for maintaining a level of domination and injustice. However, for practical reasons, the goal of ideologically balanced assessments seems a constructive point of departure in the debate as a manner to challenge and possibly decrease the asymmetric power of global corporate finance legitimized by ISA. For that purpose, if the promise of an international rule of law that produces ideologically balanced assessments is to be fulfilled, ideology must be first taken into account. The challenge of critical indeterminacy must first be addressed and the role of the dominant ideology of ISA considered in relation to its massive social, political and environmental impacts.

In this regard, it seems particularly important to explore the integration of alternative methods of legal scholarship into mainstream doctrinal work from legal education to legal practice. Even though it is beyond the scope of this work to produce any specific prescriptions as to how to proceed to such integration, it is crucial to point at that which must be avoided, more specifically, the inattentive application of doctrinal approaches that, operating as a professional reflex, uncritically perpetuate the use of a legal language already permeated by the assumptions and goals of neoliberalization. If legitimacy, understood as persuasion of the majority of the addressees of law, is expected to play a role in the grounding of international investment law and not be replaced by authoritarian imposition [21], ISA should be rethought and its practice reshaped as a forum for "ideological dialogue and evolution" [79, 70] that includes the genuine voices and the language of the populations affected, rather than practiced as a place to reinforce unpopular neoliberal policies in the name of the international rule of law ideal (cf. e.g. [119, 167, 21ff]). The work, therefore, should begin by raising awareness about the ideological dimension of IIL and rethinking the traditional doctrinal methods within ISA - and the legal profession and education more generally.

Acknowledgements I thank Evert Stamhuis, Alessandra Arcuri and Mauro Gatti for accepting to comment on previous versions of this article.

Open Access This article is licensed under a Creative Commons Attribution 4.0 International License, which permits use, sharing, adaptation, distribution and reproduction in any medium or format, as long as you give appropriate credit to the original author(s) and the source, provide a link to the Creative Commons licence, and indicate if changes were made. The images or other third party material in this article are included in the article's Creative Commons licence, unless indicated otherwise in a credit line to the material. If material is not included in the article's Creative Commons licence and your intended use is not permitted by statutory regulation or exceeds the permitted use, you will need to obtain permission directly from the copyright holder. To view a copy of this licence, visit http://creativecommons.org/licen ses/by/4.0/.

\section{References}

1. Abdullah, Al Faruque. 2010. Mapping the Relationship Between Investment Protection and Human Rights. Journal of World Investment Trade 11(4): 539-560.

2. Altman, Andrew. 1986. Legal Realism, Critical Legal Studies, and Dworkin. Philosophy \& Public Affairs 15(3): 205-235. 
3. Altman, Andrew. 1990. Critical Legal Studies. A Liberal Critique. Princeton: Princeton University Press.

4. Álvarez, José E. 2009. Contemporary Foreign Investment Law: An Empire of Law or the Law of Empire. Alabama Law Review 60(4): 943-976.

5. Zárate, Álvarez., and José Manuel. 2018. Legitimacy Concerns of the Proposed Multilateral Investment Court: Is DEMOCRACY POSSIBLE. Boston College Law Review 59(8): 2765-2790.

6. Arcuri, Alessandra, and Francesco Montanaro. 2018. Justice for All: Protecting the Public Interest in Investment Treaties. Boston College Law Review 59(8): 2791-2824.

7. Balkin, Jack M. 1986. The Crystalline Structure of Legal Thought. Rutgers Law Review 39(1): $1-110$.

8. Balkin, Jack M. 1987. Taking Ideology Seriously: Ronald Dworkin and the CLS Critique. UMKC Law Review 55: 392-433.

9. Balkin, Jack M. 1987. Deconstructive Practice and Legal Theory. Yale Law Journal 96: 743-786.

10. Beckett, Jason A. 2012. Faith and Resignation. A Journey Through International Law. In New Critical Legal Thinking. Law and the Political, ed. Matthew Stone, Illan Rua Wall, and Costas Douzinas, 145-166. New York: Routledge.

11. Bedner, Adriaan. 2010. An Elementary Approach to the Rule of Law. Hague Journal on the Rule of Law 2: 48-74.

12. Behn, Daniel. 2015. Legitimacy, Evolution, and Growth in Investment Treaty Arbitration: Empirically Evaluating the State-of-the-Art, Georgetown. Journal of International Law 46: 363-415.

13. Binder, Guyora. 1987. On Critical Legal Studies as Guerrilla Warfare. Georgetown Law Journal 76(1): 1-36.

14. Bjorklund, Andrea K. 2008. Investment Treaty Arbitral Decisions as Jurisprudence Constante. University of California Davis Legal Studies Research Paper, 158. https://ssrn.com/abstract=1319834. Accessed 21 Oct 2020.

15. Bogenschneider, Bret. 2016. Factual Indeterminacy in International Tax Law. BRICS Law Journal 3(3): 73-102.

16. Brabazon, Honor. 2017. Introduction: Understanding Neoliberal Legality. In Neoliberal Legality: Understanding the Role of Law in the Neoliberal Project, ed. Honor Brabazon, 1-21. New York, NY: Routledge.

17. Brekoulakis, Stavros. 2013. Systemic Bias and the Institution of International Arbitration: A New Approach to Arbitral Decision Making. Journal of International Dispute Settlement 4(3): 553-585.

18. Brest, Paul. 1982. Interpretation and Interest. Stanford Law Review 34(4): 765-773.

19. Brower, Charles Hendrickson, II. 2003. Structure, Legitimacy, and NAFTA's Investment Chapter. Vanderbilt Journal of Transnational Law 36: 37-94.

20. Brudney, Daniel. 1993. Two Links of Law and Morality. Ethics 103: 280-301.

21. Bruff, Ian. 2014. The Rise of Authoritarian Neoliberalism. Rethinking Marxism 26(1): 113-129.

22. Calamita, N. Jansen. 2014. The Principle of Proportionality and the Problem of Indeterminacy in International Investment Treaties. Yearbook of International Investment Law and Policy 4: 157-200.

23. Calo, Ryan. 2019. Privacy Law's Indeterminacy. Theoretical Inquiries in Law 20(1): 33-52.

24. Carpentier, Mathieu, et al. 2017. Droit et indétermination. Droit et Philosophie 9(1): 5-133.

25. Cohen, Amy J. 2009. Dispute Systems Design, Neoliberalism, and the Problem of Scale. Harvard Negotiation Law Review 14(1): 51-80.

26. Coombe, Rosemary J. 1989. Room for Manoeuver: Toward a Theory of Practice in Critical Legal Studies. Law \& Social Inquiry 14: 69-121.

27. Cooper, Frederick. 2012. Social Rights and Human Rights in the Time of Decolonization. Humanity 3: 473-492.

28. Craig, Paul P. 1997. Formal and Substantive Conceptions of the Rule of Law: An Analytical Framework. Public Law 12(Autumn): 467-487.

29. Crawford, James. 2012. Brownlie's Principles of Public International law. 8th ed. Oxford: Oxford University Press.

30. Derrida, Jacques. 2001. Structure, Sign and Play in the Discourse of the Human Sciences. In Writing and Difference, ed. Alan Bass, 351-370. New York: Routledge.

31. Dixon, Martin. 2002. International Law. London: Blackstone Press.

32. Dolzer, Rudolf. 2005. Fair and Equitable Treatment: A Key Standard in Investment Treaties. The International Lawyer 39(1): 87-106. 
33. Dolzer, Rudolf. 2013. Fair and Equitable Treatment: Today's Contours. Santa Clara Journal of International Law 12(1): 7-34.

34. Donnelly, Jack. 2013. Universal Human Rights in Theory and Practice. New Delhi: Manas Publications and Cornell University Press.

35. Draguiev, Deyan. 2014. Bad Faith Conduct of States in Violation of the 'Fair and Equitable Treatment' Standard in International Investment Law and Arbitration. Journal of International Dispute Settlement 5: 273-305.

36. Dumberry, Patrick. 2017. The Importation of "Better" Fair and Equitable Treatment Standard Protection Through MFN Clauses: An analysis of NAFTA Article 1103. Transnational Dispute Management 14(1): 1-16.

37. Dworkin, Ronald. 1977. Taking Rights Seriously. New ed. 1997. London: Bloomsbury Academic.

38. Eberhardt, Pia, and Cecilia Olivet. 2012. Profiting from Injustice: How Law Firms, Arbitrators and Financiers are Fueling an Investment Arbitration Boom. Brussels/Amsterdam: Corporate Europe Observatory and Transnational Institute. https://www.tni.org/files/download/profitingfrominjusti ce.pdf. Accessed 21 Oct 2020.

39. Edmundson, William A. 1996. The Antinomy of Coherence and Determinacy. Iowa Law Review 82(1): 1-20.

40. Evseev, Dmitri. 2009. Living with Indeterminacy: A Practical Approach to ICSID Annulment Reasoning. Investment Treaty Arbitration and International Law 2. https://arbitrationlaw.com/libra ry/living-indeterminacy-practical-approach-icsid-annulmenet-reasoning-chapter-9-investment-0. Accessed 21 Oct 2020.

41. Fasterling, Björn., and Geert Demuijnck. 2013. Human Rights in the Void? Due Diligence in the UN Guiding Principles on Business and Human Rights. Journal of Business Ethics 116: 799-814.

42. Fauchald, Ole Kristian. 2008. The Legal Reasoning of ICSID Tribunals: An Empirical Analysis. European Journal of International Law 19(2): 301-364.

43. Faure, Michael, and Wanli Ma. 2020. Investor-State Arbitration: Economic and Empirical Perspectives. Michigan Journal of International Law 41(1): 1-61.

44. Feldman, Mark. 2017. Investment Arbitration Appellate Mechanism Options: Consistency, Accuracy, and Balance of Power. ICSID Review 32(3): 528-544.

45. Fox-Decent, Evan. 2008. Is the Rule of Law Really Indifferent to Human Rights? Law and Philosophy 27: 533-581.

46. Francioni, Francesco. 2009. Access to Justice, Denial of Justice and International Investment Law. European Journal of International Law 20(3): 729-747.

47. Franck, Susan. 2005. The Legitimacy Crisis in Investment Treaty Arbitration: Privatizing Public International Law Through Inconsistent Decisions. Fordham Law Review 73: 1521-1625.

48. Franck, Thomas M. 1995. Fairness in International Law and Institutions. New York: Oxford University Press.

49. Fuller, Lon L. 1969. The Morality of Law. Revised. New Haven and London: Yale University Press.

50. Garcia, Franck J., Lindita Ciko, Apurv Gaurav, and Kirrin Hough. 2015. Reforming the International Investment Regime: Lessons from International Trade Law. Journal of International Economic Law 18: 861-892.

51. Geuss, Raymond. 1981. The Idea of a Critical Theory. Habermas \& the Frankfurt School. Cambridge: Cambridge University Press.

52. Giorgetti, Chiara. 2013. Is the Truth in the Eyes of the Beholder the Perils and Benefits of Empirical Research in International Investment Arbitration. Santa Clara Journal of International Law 12(1): 263-276.

53. Goodrich, Peter. 1987. Legal Discourse. Studies in Linguistics, Rhetoric and Legal Analysis. Hampshire: MacMillan Press.

54. Graff, Gerald. 1988. Keep off the Grass, Drop Dead, and Other Indeterminacies: A Response to Sanford Levinson. In Interpreting Law and Literature. A Hermeneutic Reader, ed. Sanford Levinson and Steven Mailloux, 175-180. Evanston: Northwestern University Press.

55. Günther, Philipp. 2020. Groupthink bias in International Adjudication. Journal of International Dispute Settlement 11: 91-126.

56. Haas, Peter M. 1992. Introduction: Epistemic Communities and International Policy Coordination. International Organization 46(1): 1-35.

57. Hafner-Burton, Emilie M., Sergio Puig, and David G. Victor. 2016. Against International Settlement? The Social Cost of Secrecy in International Adjudication. UC San Diego ILAR Working 
Paper 26. https://ilar.ucsd.edu/_files/publications/working-papers/working-paper-26.pdf. Accessed 21 Oct 2020.

58. Haque, Adil Ahmad. 2019. Indeterminacy in the Law of Armed Conflict. International Law Studies 95: 118-160.

59. Harrison, James. 2012. An Evaluation of the Institutionalisation of Corporate Human Rights Due Diligence. Warwick School of Law Research Paper No. 2012/18. Available at SSRN: https://ssrn. com/abstract=2117924. Accessed 21 Oct 2020.

60. Harvey, David. 2005. A Brief History of Neoliberalism. Oxford, New York: Oxford University Press.

61. Higgins, Rosalyn. 2010. Ethics and International Law. Leiden Journal of International Law 23: $277-289$.

62. Horwitz, Morton J. 1977. The Rule of Law: An Unqualified Human Good? Yale Law Journal 86(3): 561-566.

63. Hunt, Alan. 1985. The Ideology of Law: Advances and Problems in Recent Applications of the Concept of Ideology to the Analysis of Law. Law \& Society Review 19(1): 11-37.

64. Hunt, Alan. 1986. The Theory of Critical Legal Studies. Oxford Journal of Legal Studies 6(1): $1-45$.

65. Hippolyte, Antonius R. 2015. Aspiring for a Constructive TWAIL Approach Towards the International Investment Regime. In International Investment Law and Development: Bridging the Gap, ed. Stephan W. Schill, et al., 180-219. Cheltenhan: Edward Elgar.

66. Infantino, Marta. 2014. International Arbitral Awards' Reasons: Surveying the State-of-the-Art in Commercial and Investment International Dispute Settlements. Journal of International Dispute Settlement 5: 175-197.

67. Ishikawa, Tomoko. 2019. Counterclaims and the Rule of Law in Investment Arbitration. American Journal of International Law Unbound 113: 33-37.

68. Jacob, Marc, and Stephan W. Schill. 2015. Fair and Equitable Treatment: Content, Practice, Method. In International Investment Law: A Handbook, eds. Marc Bungenberg et al., 700-763. Nomos/CH Beck/Hart: Baden-Baden/München/Oxford. Amsterdam Law School Research Paper No. 2017-24, Amsterdam Center for International Law No. 2017-20. Available at SSRN: https:// ssrn.com/abstract=2933425. Accessed 21 Oct 2020.

69. Jaff, Jennifer. 1986. Frame-Shifting: An Empowering Methodology for Teaching and Learning Legal Reasoning. Journal of Legal Education 35: 249-267.

70. Kairys, David. 1998. Introduction. In The Politics of Law. A Progressive Critique. 3rd ed., ed. David Kairys, 1-20. New York, NY: Basic Books.

71. Karton, Joshua. 2015. The Arbitral Role in Contractual Interpretation. Journal of International Dispute Settlement 6: 4-41.

72. Kelman, Mark. 1987. A Guide to Critical Legal Studies. Cambridge, MA: Harvard University Press.

73. Kennedy, David. 1985. The Turn to Interpretation. Southern California Law Review 58: 251-275.

74. Kennedy, David. 2005. Challenging Expert Rule: The Politics of Global Governance. Sydney Law Review 27(1): 5-28.

75. Kennedy, David. 2006. The "Rule of Law", Political Choices, and Development Common Sense. In The New Law and Economic Development. A Critical Appraisal, ed. David M. Trubek and Alvaro Santos, 95-173. NY: Cambridge University Press.

76. Kennedy, Duncan. 1973. Legal Formality. Journal of Legal Studies 2: 351-398.

77. Kennedy, Duncan. 1976. Form and Substance in Private Law Adjudication. Harvard Law Review 89: 1685-1778.

78. Kennedy, Duncan. 1986. Freedom and Constraint in Adjudication: A Critical Phenomenology. Journal of Legal Education 36: 518-562.

79. Kennedy, Duncan. 1998. A critique of adjudication: fin de siècle. Cambridge, MA: Harvard University Press.

80. Kennedy, Duncan. 2001. A Semiotics of Critique. Cardozo Law Review 22: 1147-1189.

81. Kornfeld, Itzchak E. 2013. Comment on Erns-Ulrich Petersmann's 'The Judicial Task of Administering Justice in Trade and Investment Law and Adjudication.' Journal of International Dispute Settlement 4(2): 219-226.

82. Koskenniemi, Marti. 2005. From Apology to Utopia: The Structure of International Legal Argument. NY: Cambridge University Press. 
83. Krajewski, Markus. 2018. Human Rights in International Investment Law: Recent Trends in Arbitration and Treaty-Making Practice. Available at SSRN: https://ssrn.com/abstract=3133529. Accessed 21 Oct 2020.

84. Kriebaum, Ursula. 2018. Evaluation Social Benefits and Costs of Investment Treaties: Depoliticization of Investment Disputes. ICSID Review 33(1): 14-28.

85. Kumm, Mattias. 2016. An Empire of Capital? Transatlantic Investment Protection as the Protection of Illegitimate Investor Privileges. In Wissenschaftszentrum Berlin für Sozialforschung [WZB] Report 2016: 43-46. https://bibliothek.wzb.eu/articles/2016/f-20253.pdf. Accessed 21 Oct 2020.

86. Kutz, Christopher L. 1994. Just Disagreement: Indeterminacy and Rationality in the Rule of Law. Yale Law Journal 103: 997-1030.

87. Lalive, Pierre. 2010. On the Reasoning of International Arbitral Awards. Journal of International Dispute Settlement 1(1): 55-65.

88. Lanius, David. 2019. Strategic Indeterminacy in the Law. New York: Oxford University Press.

89. Lasser de S-O-1'E, Mitchel. 2001. Do Judges Deploy Policy? Cardozo Law Review 22: 863-899.

90. Linderfalk, Ulf. 2015. Is Treaty Interpretation an Art or a Science? International Law and Rational Decision Making. European Journal of International Law 26(1): 169-189.

91. MacCormick, Neil. 2005. Rhetoric and the Rule of Law: A Theory of Legal Reasoning. New York, NY: Oxford University Press.

92. Mann, Howard. 2008. International Investment Agreements, Business and Human Rights: Key Issues and Opportunities. International Institute for Sustainable Development. https://www.iisd. org/sites/default/files/publications/iia_business_human_rights.pdf. Accessed 21 Oct 2020.

93. Marks, Susan. 2001. Big Brother is Bleeping Us: With the Message that Ideology Doesn't Matter. European Journal of International Law 12(1): 109-123.

94. Marks, Susan. 2009. False Contingency. Current Legal Problems 62(1): 22-70.

95. Mootz, Francis J. 1993. Is the Rule of Law Possible in a Postmodern World? Washington Law Review 68(2): 249-306.

96. Munger, Franck, and Carroll Seron. 1984. Critical Legal Studies Versus Critical Legal Theory: A Comment on Method. Law \& Policy 6(3): 257-297.

97. Nicol, Danny. 2011. Business Rights as Human Rights. In The Legal Protection of Human Rights: Skeptical Essays, ed. Tom Campbell, et al., 229-243. New York, NY: Oxford University Press.

98. Norton, Patrick M. 2018. The Role of Precedent in the Development of International Investment Law. ICSID Review 33(1): 280-301.

99. Odumosu, Ibironke T. 2007. The Law and Politics of Engaging Resistance in Investment Dispute Settlement. Penn State International Law Review 26(2): 251-287.

100. Okpe, Felix O. 2017. A Historical Account of the Internationalization of Invest Disputes: What the Global South Should know When Negotiating Bilateral Investment Treaties. Florida A\&M University Law Review 12(2): 219-246.

101. Orellana, Marcos A. 2006. The Role of Science in Investment Arbitrations Concerning Public Health and the Environment. Yearbook of International Environmental Law 17: 48-72.

102. Ortino, Federico. 2012. Legal Reasoning in International Investment Tribunals: A Typology of Egregious Failures. Journal of International Dispute Settlement 3(1): 31-52.

103. Otto, Dianne. 1996. Subalternity and International Law: The Problems of Global Community and the Incommensurability of Difference. Social \& Legal Studies 5(3): 337-364.

104. Paine, Joshua. 2015. The Project of System-Internal Reform in International Investment Law: An Appraisal. Journal of International Dispute Settlement 6: 332-354.

105. Paul, Jeremy. 2001. CLS 2001. Cardozo Law Review 22: 701-720.

106. Peat, Daniel. 2018. International Investment Law and the Public Law Analogy: The Fallacies of the General Principles Method. Journal of International Dispute Settlement 9: 654-678.

107. Perrone, Nicolás M. 2017. The Emerging Global Right to Investment: Understanding the Reasoning Behind Foreign Investor Rights. Journal of International Dispute Settlement 8: 673-694.

108. Petersmann, Ernst-Ulrich. 2013. The Judicial Task of Administering Justice in Trade and Investment Law and Adjudication. Journal of International Dispute Settlement 4(1): 5-28.

109. Peterson, Luke Eric, and Kevin R. Grey. 2003. International Human Rights in Bilateral Investment Treaties and in Investment Treaty Arbitration. International Institute for Sustainable Development. https://www.iisd.org/publications/international-human-rights-bilateral-investment-treaties-andinvestment-treaty. Accessed 21 Oct 2020.

110. Piccioto, Sol. 2015. Indeterminacy, Complexity, Technocracy and the Reform of International Corporate Taxation. Social \& Legal Studies 24(2): 165-184. 
111. Pohl, Joachim. 2018. Societal Benefits and Costs of International INVESTMENT Agreements: A Critical Review of Aspects and Available Empirical Evidence. OECD Working Papers on International investment 2018[1]. www.oecd.org/daf/inv/investment-policy/working-papers.htm. Accessed 21 Oct 2020.

112. Posner, Richard A. 1988. The Jurisprudence of Skepticism. Michigan Law Review 86(5): 827-891.

113. Posner, Richard A. 1988. Conventionalism: The Key to Law as an Autonomous Discipline. University of Toronto Law Journal 38(4): 333-354.

114. Prieto-Ríos, Enrique. 2015. Neoliberal Market Rationality: The Driver of International Investment Law. Birkbeck Law Review 3(1): 55-76.

115. Puchkov, Stepan. 2018. Subconscious Bias as a Factor Influencing Arbitral Decision-Making. International Journal of Arbitration, Mediation and Dispute Management 84(1): 52-76.

116. Puig, Sergio, and Gregory Schaffer. 2018. Imperfect Alternatives: Institutional Choices and the Reform of Investment Law. American Journal of International Law 112(3): 361-409.

117. Puppo, Alberto. 2016. Reasonable Stability vs. Radical Indeterminacy: A Disanalogy Between Domestic Rule of Law and Humanity-Based International Law. Revus: Journal for Constitutional Theory and Philosophy of Law 30: 81-102.

118. Rajkovic, Nikolas M. 2014. Rules, Lawyering, and the Politics of Legality: Critical Sociology and International Law's Rule. Leiden Journal of International Law 27(2): 331-352.

119. Reinisch, August, Andrea Bjorklund and Andreas R. Ziegler. 2018. Rule of Law and International Investment Law: Report on the Sydney Conference [2018]. International Law Association's Committee on the Rule of Law and International Investment Law. https://www.ila-hq.org/ index.php/committees. Accessed 21 Oct 2020.

120. Reynolds, John. 2012. The Political Economy of States of Emergency. Oregon Review of International Law 14(1): 85-130.

121. Ridi, Niccolò. 2019. The Shape and Structure of the 'Usable Past': An Empirical Analysis of the Use of Precedent in International Adjudication. Journal of International Dispute Settlement 10: 200-247.

122. Roberts, Anthea. 2010. Power and Persuasion in Investment Treaty Interpretation: The Dual Role of States. American Journal of International Law 104(2): 179-255.

123. Roberts, Anthea. 2018. Incremental, Systemic, and Paradigmatic Reform of Investor-State Arbitration. American Journal of International Law 112(3): 410-432.

124. Sartorius, Rolf. 1971. Social Policy and Judicial Legislation. American Philosophical Quarterly 8(2): 151-160.

125. Schill, Stephan W. 2010. Fair and Equitable Treatment, the Rule of Law and Comparative Public Law. In International Investment Law and Comparative Public Law, ed. Stephan W. Schill, 151-182. Oxford: Oxford University Press.

126. Schill, Stephan W. 2010. Crafting the International Economic Order: The Public Function of Investment Treaty Arbitration and Its Significance for the Role of the Arbitrator. Leiden Journal of International Law 23(2): 401-430.

127. Schill, Stephan W. 2014. International Investment Law and the Rule of Law. In Rule of Law Symposium 2014: The Importance of the Rule of Law in Promoting Development, Eds. Jeffrey Lowell, J. Christopher Thomas and Jan van Zyl Smit, 81-102. Singapore: Academy Publishing. Amsterdam Law School Research Paper No. 2017-18, Amsterdam Center for International Law No. 2017-15. SSRN: https://ssrn.com/abstract=2932153. Accessed 21 Oct 2020.

128. Schlag, Pierre. 1988. Cannibal Moves: An Essay on the Metamorphoses of the Legal Distinction. Stanford Law Review 40(4): 929-972.

129. Schlag, Pierre, and David Skover. 1986. Tactics of Legal Reasoning. Durham: Carolina Academic Press.

130. Schneiderman, David. 2010. Judicial Politics and International Investment Arbitration: Seeking an Explanation for Conflicting Outcomes. Northwestern Journal of International Law and Business 30(2): 383-416.

131. Schokkaert, Jan, and Yvon Heckscher. 2010. Investment Contracts Between Sovereign States and Private Companies: Link Between Bits and State Contracts. Journal of World Investment Trade 11(6): 903-964.

132. Schultz, Thomas, and Cédric. Dupont. 2015. Investment Arbitration: Promoting the Rule of Law or Over-Empowering Investors? A Quantitative Empirical Study. European Journal of International Law 25(4): 1147-1168. 
133. Shalakany, Amr A. 2000. Arbitration and the Third World: Plea for Reassessing Bias Under the Specter of Neoliberalism. Harvard International Law Journal 41(2): 419-468.

134. Simma, Bruno. 2011. Foreign Investment Arbitration: Place for Human Rights. International and Comparative Law Quarterly 60(3): 573-596.

135. Singer, Joseph W. 1984. The Player and the Cards: Nihilism and Legal Theory. Yale Law Journal 94(1): 1-70.

136. Slobodian, Quinn. 2018. Globalists: The End of Empire and the Birth of Neoliberalism. Cambridge, MA: Harvard University Press.

137. Sornrajah, Muthucumaraswamy. 2006. Power and justice: third world resistance in international law. Singapore Year Book of International Law 10: 19-57.

138. Sornarajah, Muthucumaraswamy. 2011. Mutations of Neo-liberalism in International Investment Law. Trade, Law and Development 3(1): 203-232.

139. Sornarajah, Muthucumaraswamy. 2018. The Unworkability of "Balanced Treaties" and the Importance of Diversity of Approach Among the BRICS. American Journal of International Law Unbound 112: 223-227.

140. Spears, Suzanne A. 2010. The Quest for Policy Space in a New Generation of International Investment Agreements. Journal of International Economics 13(4): 1037-1075.

141. St John, Taylor. 2018. The Rise of Investor-State Arbitration: Politics, Law, and Unintended Consequences. Oxford University Press. https://doi.org/10.1093/oso/9780198789918.001.0001.

142. Staten, Henry. 1984. Wittgenstein and Derrida. Lincoln: University of Nebraska Press.

143. Stavropoulos, Nicos. 2014. Legal Interpretivism. The Stanford Encyclopedia of Philosophy. https:// plato.stanford.edu/archives/sum2014/entries/law-interpretivist/. Accessed 21 Oct 2020.

144. Stein, Robert. 2009. Rule of Law: What Does it Mean? Minnesota Journal of International Law 18: 293-303.

145. Tamanaha, Brian Z. 2004. On the Rule of Law: History, Politics, Theory. Cambridge: Cambridge University Press.

146. Tanzi, Attila. 2012. On Balancing Foreign Investment Interests with Public Interests in Recent Arbitration Case Law in the Public Utilities Sector. The Law and Practice of International Courts and Tribunals 11:47-76.

147. Tasioulas, John. 2018. The Rule of Law. In John 147 [ed.], The Cambridge Companion to the Philosophy of Law. Cambridge University Press, 2019. King's College London Law School Research Paper No. 2018-21, Available at SSRN: https://ssrn.com/abstract=3216796. Accessed 21 Oct 2020.

148. Thomas, J. Christopher., and Harpreet Kaur Dhillon. 2017. The Foundations of Investment Treaty Arbitration: The ICSID Convention, Investment Treaties and the Review of Arbitration Awards. ICSID Review 32(3): 459-502.

149. Tudor, Ioana. 2008. The Fair and Equitable Treatment Standard in the International Law of Foreign Investment. Oxford: Oxford University Press.

150. UNCTAD. 2012. Fair and Equitable Treatment. UNCTAD Series on Issues in International Investment Agreements II. NY Geneva: United Nations. https://unctad.org/en/docs/unctaddiaeia2011d5_ en.pdf. Accessed 21 Oct 2020.

151. Unger, Roberto M. 1977. Law in Modern Society: Toward a Criticism of Social Theory. New York, NY: The Free Press.

152. Unger, Roberto M. 1986. The Critical Legal Studies Movement. Cambridge, MA: Harvard University Press.

153. Ureña, René. 2014. Of Precedents and Ideology. Law making by Investment Arbitration Tribunals. In Critical International Law: Postrealism, Postcolonialism, and Transnationalism, ed. Prabhakar Singh and Benoit Mayer, 276-303. New Delhi: Oxford University Press.

154. Vagts, Detlv F. 1993. Treaty Interpretation and the New American Ways of Law Reading. European Journal of International Law 4: 472-505.

155. Van Harten, Gus, et al. 2010. Public Statement on the International Investment Regime-31 August 2010. https://www.osgoode.yorku.ca/public-statement-international-investment-regime-31-augus t-2010/. Accessed 21 Oct 2020.

156. Van Harten, Gus. 2012. Arbitrator Behaviour in Asymmetrical Adjudication: An Empirical Study of Investment Treaty Arbitration. Osgoode Hall Law Journal 50(1): 211-268.

157. Vandevelde, Kenneth J. 2000. Economics of Bilateral Investment Treaties. Harvard International Law Journal 41(2): 469-502. 
158. Waibel, Michael. 2011. Demystifying the Art of Interpretation. European Journal of International Law 22(2): 571-588.

159. Waldron, Jeremy. 2002. Is the Rule of Law an Essentially Contested Concept [in Florida]? Law and Philosophy 21(2): 137-164.

160. Wang, Keren. 2020. Legal and Rhetorical Foundations of Economic Globalization. New York, NY: Routledge.

161. Weinstein, Morgan L. 2015. Indeterminacy by Omission: Who Decides Whether Regulation X Applies? Unbound Harvard Journal of the Legal Left 10: 94-97.

162. Wettstein, Florian. 2015. Normativity, Ethics, and the UN Guiding Principles on Business and Human Rights: A Critical Assessment. Journal of Human Rights 14(2): 162-182.

163. Wills, Joe. 2014. The World Turned Upside Down: Neo-liberalism, Socioeconomic Rights, and Hegemony. Leiden Journal of International Law 27(1): 11-36.

164. Wittgenstein, Ludwig. 2009. Philosophical Investigations. Trans. G.E.M. Anscombe et al. Oxford: Wiley-Blackwell.

165. Wythes, Annika. 2010. Investor-State Arbitrations: Can the Fair and Equitable Treatment Clause Consider International Human Rights Obligations? Leiden Journal of International Law 23(1): 241-256.

166. Zapf, Christian, and Eben Moglen. 1996. Linguistic Indeterminacy and the Rule of Law: On the Perils of Misunderstanding Wittgenstein. Georgetown Law Journal 84: 485-520.

167. Zivkovic, Velimir. 2020. Pursuing and Reimagining the International Rule of Law Through International Investment Law. Hague Journal on the Rule of Law 12: 1-27.

168. Rogers, Catherine A. 2013. The Politics of International Investment Arbitrators. Santa Clara Journal of International Law 12(1): 223-262.

Publisher's Note Springer Nature remains neutral with regard to jurisdictional claims in published maps and institutional affiliations. 